\title{
Potentiality of Using Mycorrhizae and Pseudomonas fluorescens in Reducing the Effect of Water Shortage on Broccoli Plants
}

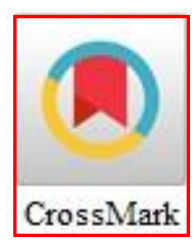

\section{Dalia A Abd El-Fattah ${ }^{*}$, Fadl A Hashem², Ahmed A Farag}

1- Biological Agricultural Department, Central Laboratory for Agricultural Climate, Agricultural Research Centre, 12411, Giza, Egypt

2- Agrometeorological Application Department, Central Laboratory for Agricultural Climate, Agricultural Research Centre, 12411, Giza, Egypt

3- Climate Modification Department, Central Laboratory for Agricultural Climate, Agricultural Research Centre 12411, Giza, Egypt

* Corresponding author: Dalia.a.abdel-Fattah@arc.Sci.eg

DOI:10.21608/ajs.2021.98841.1424

Received 4 October, 2021 ; Accepted 8 December, 2021

\section{Keywords}

Arbuscular mycorrhiza, Pseudomonas fluorescens, Microbial inoculants, Water use efficiency, Broccoli

\section{Introduction}

Broccoli (Brassica oleracea L. var. italica) belongs to the Brassicaceae family that is mainly found over the Mediterranean territory. Broccoli floret is enriched with minerals particularly $\mathrm{Ca}, \mathrm{K}$, $\mathrm{S}, \mathrm{P}, \mathrm{Mg}$, in addition to micro-elements (Jigme et al 2015). A previous study (Zaicovski et al 2008) showed that broccoli plants subjected to water

\begin{abstract}
Accelerating global warming and water scarcity and improving water use efficiency are considered essential factors for achieving adequate crop development and productivity. Therefore, the authors targeted the use of arbuscular mycorrhizal fungi (AMF) and Pseudomonas fluorescens (Ps1) for improving growth, productivity, and water use efficiency of broccoli plants (Brassica olercea $\mathrm{L}$. var. italica, cv. Belstar $\mathrm{F}_{1}$ ) under various irrigation regimes i.e., 50, 75, and 100\% of crop evapotranspiration (ETc). Two greenhouse experiments were carried out in clayey soil. The combined inoculation of endomycorrhizae and Ps. fluorescens (Ps1) improved water use efficiency and consequently vegetative growth and yield. Under the applied irrigation regime $75 \%$ ETc of broccoli inoculated with both endomycorrhizae and $P S$. fluorescens (Ps1) showed higher head weight (616 and 647 gram) than those grown under the irrigation regime $75 \%$ ETc combined with endomycorrhizae (568 and 559 gram) during the two seasons, respectively. However, a minimum yield value of 149 and 142 grams per plant was recorded for uninoculated plants grown under 50\% irrigation regime during both seasons. In conclusion, the combined inoculation with endomycorrhizae and Ps. fluorescens (Ps1) under irrigation regime $75 \%$ ETc was the optimum combination for increasing water stress resistance and broccoli productivity under water scarcity circumstances.
\end{abstract}

stress during the floret process were greener and more turgid additionally a decrease in crop output when compared to broccoli plants subjected to daily irrigation (Patle et al 2018).

Water has become a strategic priority risen on the top of the resource list due to population growth and climate change, which is already taking place and representing one of the most serious environmental challenges to our planet. Nowadays, plenty of studies were 
conducted to investigate the optimal water demands under drought conditions to obtain the maximum crop productivity for sustainable agriculture development. Furthermore, pinpointing drought-resistant crop cultivars for each climatic element has become the main issue. (Durak and Yildırım 2017).

Mycorrhizae is the most widespread plant growth-promoting fungi that make a mutualistic relationship with plant roots and is capable of improving the nutritional status, growth, and productivity of various plants (Feddermann et al 2010). Under water stress, arbuscular mycorrhizal fungi (AMF) promote plant resistance by enlarging the surface root area into the soil and expanding their ramifying hyphae to the obtainable moisture zones for continual water absorption and translocation to plants (Smith and Read 2008). In addition, AMF increases the plant resistance to drought and improves the water-use efficiency of crops through supporting alternative physiological pathways (Abdel-Salam et al 2017).

Pseudomonas fluorescens is one of the wellknown plant growth-promoting rhizobacteria (PGPR), in the soil that stimulate plant growth and development, as well as immune systemic resistance (Qessaoui et al 2019).

Both AMF and Pseudomonas fluorescens, are vital parts of soil microorganisms, since they have a significant impact on plant growth, especially under stress conditions through influencing numerous crucial plant physiological processes, such as seed germination ratio, root development, and branching, photosynthetic rates, and phytohormone balance in the plants. Soil remediation, like re-aggregation of soil particles, ameliorate soil $\mathrm{pH}$ and salinity (Cheng et al 2021, Ahanger et al 2014).

The current study was carried out to investigate the potentiality of using AMF fungi and Pseudomonas fluorescens on broccoli plant's productivity and water use efficiency under different irrigation levels.

\section{Materials and methods}

\subsection{Microorganisms treatment}

Ps. fluorescens (Ps1) and a mixture of arbuscular mycorrhizal fungi (AMF) with a dominant Glomus sp. were obtained from Microbial Inoculants Center, Fac. Agric., Ain Shams Univ., Shubra El-Kheima, Cairo, Egypt. Each plantlet received $5 \mathrm{~mL}$ of AMF spore suspension (50 spores $/ \mathrm{ml})$.
Ps. fluorescens (Ps1) maintained on king's medium (King et al 1954) supplemented with tryptophan (1 $\mathrm{mM} / \mathrm{L}$ ) as auxin precursor, was investigated for indole acetic acid (IAA), cytokinins, and gibberellic acid using (HPLC) according to Tien et al (1979). Five ml culture containing $1 \times 10^{8} \mathrm{cfu} / \mathrm{ml}$, were added to each plant at planting and after one month.

\subsection{The cultivated plant}

Broccoli plant (Brassica olercea L. var. italica, cv. Belstar $F_{1}$ ) was transplanted on the $23^{\text {rd }}$ and $25^{\text {th }}$ of September 2018 and 2019, respectively. The transplants were placed in raised beds $1 \mathrm{~m}$ in width; each bed had two rows, and the plant spacing was $0.3 \mathrm{~m}$.

\subsection{Application of chemical fertilizer to broccoli seedlings}

In the control treatment, the chemical fertilizers were added during the season by the fertigation system at a rate of $66 \mathrm{~kg} \mathrm{~N}$, and $46 \mathrm{~kg} \mathrm{~K}_{2} \mathrm{O}$ per feddan as ammonium nitrate and potassium sulfate, respectively. Phosphorus was added before bed raising in the form of calcium triple superphosphate at a rate of $30 \mathrm{~kg}$ $\mathrm{P}_{2} \mathrm{O}_{5}$ per feddan as recommended by The Egyptian Ministry of Agriculture and Land Reclamation.

\subsection{Experimental design}

Two greenhouse experiments were conducted over the two successive seasons of 2018/2019 at the greenhouse of Experimental Farm of Protected Cultivation Experimental Site, Agricultural Research Center (ARC), Giza Governorate, Egypt. The experiment was designed using different combinations between three different irrigation levels (50, 75, and 100\% of crop evapotranspiration (ETc)) and two types of microbial inocula (Arbuscular mycorrhizal fungi and Pseudomonas fluorescens (Ps1)).

The experiment was arranged in a split-plot design with three replicates. The plot area was $10 \mathrm{~m}$ (length) x $2 \mathrm{~m}$ (width). Soil physical and chemical properties were examined (Table 1) as reported by Page et al (1982). With a drippers system of $4 \mathrm{~L} / \mathrm{h}$ broccoli plants were irrigated. The fertigation system was scheduled to work daily, and the duration of irrigation time was adopted according to treatments. For each irrigation level, a flowmeter (Metrotec, EGYPT) has been installed and between each irrigation treatment, two meters were left. 
Table 1. Physicochemical analysis of soil used at the experimental site (0-30 $\mathrm{cm}$ depth).

\begin{tabular}{|c|c|c|c|}
\hline \multicolumn{2}{|c|}{$\begin{array}{c}\text { Particle size distribution, } \\
\%\end{array}$} & \multicolumn{2}{|c|}{$\begin{array}{c}\text { Soluble cations, } \mathbf{m m o l}_{\mathbf{c}} \\
\qquad \mathbf{L}^{-1}\end{array}$} \\
\hline Sand & 14.1 & $\mathrm{Ca}^{2+}$ & 14.1 \\
\hline Silt & 9.00 & $\mathrm{Mg}^{2+}$ & 10.1 \\
\hline Clay & 76.9 & $\mathrm{Na}^{+}$ & 10.2 \\
\hline Textural class & Clayey & $\mathrm{K}^{+}$ & 4.82 \\
\hline $\mathrm{CaCO}_{3}, \mathrm{~g} \mathrm{~kg}^{-1}$ & 15.0 & \multicolumn{2}{|c|}{$\begin{array}{l}\text { Soluble anions, } \text { mmol }_{c} \\
\mathrm{~L}^{-1}\end{array}$} \\
\hline $\mathrm{OM}, \mathrm{g} \mathrm{kg}^{-1}$ & 10.1 & $\mathrm{CO}_{3}^{2-}$ & 0.00 \\
\hline $\mathrm{CEC}, \mathrm{cmol}_{\mathrm{c}} \mathrm{kg}^{-1}$ & 54.9 & $\mathrm{HCO}_{3}^{-}$ & 6.42 \\
\hline $\mathrm{pH}(1: 2.5)$ & 7.67 & $\mathrm{Cl}^{-}$ & 11.4 \\
\hline $\mathrm{EC}_{\mathrm{e}}, \mathrm{dS} \mathrm{m} \mathrm{m}^{-1}$ & 2.71 & $\mathrm{SO}_{4}{ }^{2-}$ & 18.6 \\
\hline
\end{tabular}

The climatic data concerning weather parameters, such as (temperatures, humidity, solar radiation, wind speed, and evapotranspiration (ETo)) during both successive cultivation seasons (2018 and 2019) were obtained from the weather station, that belongs to the Central Laboratory for Agricultural Climate are demonstrated in Table 2.

\subsection{Water requirements assessment}

The total amount of irrigation water was calculated according to the methods described by the FAO Penman-Monteith (Allen et al 1998). This method strongly predicted $\mathrm{ET}_{\mathrm{o}}$ correctly in a wide range of sites and climates. Calculations of irrigation levels were done as follow:

The potential evapotranspiration $\left(\mathrm{ET}_{\mathrm{o}}\right)$ was calculated first:

$$
E T_{o}=\frac{0.408 \Delta\left(R_{n}-G\right)+\gamma \frac{900}{T+273} u_{2}\left(e_{s}-e_{a}\right)}{\Delta+\gamma\left(1+0.34 u_{2}\right)} \quad 1
$$

Where:
$\mathrm{ET}_{\mathrm{o}}=$ reference evapotranspiration $\left(\mathrm{mm} \mathrm{day}^{-1}\right) ; \mathrm{Rn}=$ net radiation at the crop surface (MJ m ${ }^{-2}$ day $\left.^{-1}\right) ; \mathrm{G}=$ soil heat flux density $\left(\mathrm{MJ} \mathrm{m}^{-2}\right.$ day $\left.^{-1}\right)$; $\mathrm{T}=$ mean daily air temperature at $2 \mathrm{~m}$ height $\left({ }^{\circ} \mathrm{C}\right) ; \mathrm{U}_{2}$ $=$ wind speed at $2 \mathrm{~m}$ height $\left(\mathrm{m} \mathrm{s}^{-1}\right)$; es = saturation vapor pressure $(\mathrm{k} \mathrm{Pa})$; ea $=$ actual vapor pressure $(\mathrm{k} \mathrm{Pa}$ ); es - ea $=$ saturation vapor pressure deficit $(\mathrm{k} \mathrm{Pa}) ; \Delta=$ slope vapor pressure curve $\left(\mathrm{k} \mathrm{Pa}^{\circ} \mathrm{C}^{-1}\right) ; \quad \gamma=$ psychrometic constant $\left(\mathrm{k} \mathrm{Pa}^{\circ} \mathrm{C}^{-1}\right)$.

According to FAO (2012), the $2^{\text {nd }}$ step was to determine crop water consumptive use $\left(\mathrm{ET}_{\mathrm{c}}\right)$, which was calculated by multiplying the reference crop evapotranspiration, $\mathrm{ET}_{\mathrm{o}}$, by a crop coefficient, $\mathrm{K}_{\mathrm{c}}$ :

$$
\mathrm{ET}_{\mathrm{c}}=\mathrm{ET}_{\mathrm{o}} * \mathrm{~K}_{\mathrm{c}} \quad \ldots . . \mathrm{mm} / \mathrm{day}
$$

Where:

$\mathrm{ET}_{\mathrm{c}}$ crop evapotranspiration [mm day $\left.{ }^{-1}\right]$.

$\mathrm{K}_{\mathrm{c}}$ crop coefficient [dimensionless].

$\mathrm{ET}_{\mathrm{o}}$ reference crop evapotranspiration $\left[\mathrm{mm} \mathrm{day}^{-1}\right]$.

The irrigation requirements (IR) for each treatment was calculated as follows:

$\mathrm{IR}=\left(\mathrm{ET}_{\mathrm{o}} * \mathrm{~K}_{\mathrm{c}}\right) *(\mathrm{LR}) * 4.2 / \mathrm{Ea} .(\mathrm{m} 3 /$ feddan/ day $)(3)$

Where:

LR $\%=$ Leaching requirement percentage.

$\mathrm{Ea}=$ the irrigation system's efficiency (assumed to be $85 \%$ of total applied water).

Leaching requirements were calculated based on Allen et al (1998).

According to FAO (1982), the water use efficiency (WUE) is the ratio of crop productivity (y) to the total amount of irrigation water used in the field throughout the growing season (IR),

$\operatorname{WUE}\left(\mathrm{kg} / \mathrm{m}^{3}\right)=\mathrm{Y}(\mathrm{kg}) / \mathrm{IR}\left(\mathrm{m}^{3}\right)$

The irrigation water quantities for broccoli at the Dokki site throughout the two growing seasons are mentioned in Table 3. 
Table 2. Climatic conditions of the experimental site during cultivation season 2018 / 2019

\begin{tabular}{|c|c|c|c|c|c|c|c|c|c|c|c|c|}
\hline \multirow{3}{*}{ Weeks $^{\bullet}$} & \multicolumn{4}{|c|}{ Temperature $\left({ }^{\circ} \mathrm{C}\right)$} & \multicolumn{2}{|c|}{$\mathbf{R H} \bullet \bullet \bullet$} & \multirow{2}{*}{\multicolumn{2}{|c|}{$\begin{array}{c}\text { SRAD }^{\bullet \bullet} \\
\left(\mathrm{MJ} / \mathrm{m}^{\wedge} 2 / \mathrm{day}\right)\end{array}$}} & \multirow{2}{*}{\multicolumn{2}{|c|}{$\frac{\text { Wind Speed }}{(\mathrm{m} / \mathrm{s})}$}} & \multirow{2}{*}{\multicolumn{2}{|c|}{$\frac{\text { ET }_{0}}{\left(\mathrm{~mm} \mathrm{day}^{-1}\right)}$}} \\
\hline & \multicolumn{2}{|c|}{$\operatorname{Max}$} & \multicolumn{2}{|c|}{ Min } & \multicolumn{2}{|c|}{$(\%)$} & & & & & & \\
\hline & 2018 & 2019 & 2018 & 2019 & 2018 & 2019 & 2018 & 2019 & 2018 & 2019 & 2018 & 2019 \\
\hline 1 & 36.2 & 38.8 & 20.0 & 22.5 & 47.6 & 42.4 & 21.4 & 25.8 & 2.56 & 2.56 & 3.79 & 3.96 \\
\hline 2 & 34.8 & 37.6 & 21.6 & 21.7 & 51.6 & 44.0 & 18.8 & 25.1 & 3.14 & 2.58 & 3.74 & 3.65 \\
\hline 3 & 31.3 & 36.7 & 18.1 & 21.4 & 53.0 & 46.1 & 19.2 & 23.9 & 2.51 & 2.97 & 3.70 & 3.34 \\
\hline 4 & 30.4 & 35.6 & 17.2 & 20.7 & 56.7 & 48.9 & 18.2 & 22.3 & 2.27 & 2.87 & 3.69 & 3.16 \\
\hline 5 & 30.9 & 35.3 & 18.1 & 19.9 & 45.8 & 47.4 & 16.9 & 22.1 & 2.81 & 2.89 & 2.72 & 3.09 \\
\hline 6 & 31.7 & 34.7 & 15.0 & 19.4 & 46.6 & 47.7 & 17.1 & 21.0 & 2.97 & 2.45 & 2.79 & 2.60 \\
\hline 7 & 27.0 & 34.9 & 15.3 & 19.8 & 57.8 & 46.0 & 14.1 & 20.0 & 1.73 & 2.75 & 2.66 & 2.81 \\
\hline 8 & 25.3 & 35.1 & 13.7 & 19.3 & 57.9 & 51.6 & 13.6 & 19.0 & 2.12 & 2.68 & 2.17 & 2.37 \\
\hline 10 & 26.3 & 31.1 & 13.9 & 19.2 & 58.7 & 54.0 & 13.2 & 15.6 & 2.25 & 2.96 & 2.26 & 2.28 \\
\hline 11 & 24.4 & 27.9 & 12.8 & 16.5 & 54.2 & 65.4 & 12.8 & 15.0 & 1.78 & 2.74 & 2.11 & 2.00 \\
\hline
\end{tabular}

$*$ The cultivation date started on $23^{\text {rd }}$ and $25^{\text {th }}$ September during the two studied seasons, respectively, and the experiment ended in the middle of December.

$\bullet^{\bullet} \mathrm{SRAD}=$ Solar Radiation $\left(\mathrm{MJ} / \mathrm{m}^{2} / \mathrm{day}\right),{ }^{\bullet \bullet} \mathrm{RH}=$ Relative Humidity, $\mathrm{ET}_{\mathrm{o}}=$ Evapotranspiration (mm/day).

Table 3. The average of irrigation requirements for broccoli plants under different irrigation levels

\begin{tabular}{|c|c|c|c|c|c|}
\hline \multicolumn{4}{|c|}{ Irrigation Requirements, $\mathbf{m}^{3} /$ feddan } \\
\hline \multicolumn{3}{|c|}{ Season 2018 } & \multicolumn{3}{c|}{ Season 2019 } \\
\hline $100 \%$ & $75 \%$ & $50 \%$ & $100 \%$ & $75 \%$ & $50 \%$ \\
\hline 2580 & 1935 & 1290 & 2648 & 1986 & 1324 \\
\hline
\end{tabular}

\subsection{Parameters measured}

\subsubsection{Ps. fluorescens (Ps1) population densities in the rhizosphere of broccoli plants}

Total viable counts (cfu/g) of Ps. fluorescens (Ps1) was determined in the rhizosphere using the standard plate count on king's agar medium (King et al 1954) where three plants were randomly selected from each experimental plot at zero time, after 30,60, and 90 days after sowing in each season.

\subsubsection{Arbuscular mycorrhizal fungi (AMF) root colonization}

Three plants were randomly selected from each experimental plot after two months from infection to estimate mycorrhizal root infection ratio by visual observation of fungal colonization according to Phillips and Hayman (1970).

\subsubsection{Plant growth parameters}

Three plants were randomly selected from each experimental plot to estimate the growth pa- rameters and yield of broccoli. The number of leaves per plant, fresh weight (g/plant), head weight $(\mathrm{g})$, head length $(\mathrm{cm})$, and head width $(\mathrm{cm})$ were determined.

\subsubsection{Biochemical analysis of the leaves}

The selected broccoli leave samples were ovendried and digested in $\mathrm{H}_{2} \mathrm{SO}_{4} / \mathrm{H}_{2} \mathrm{O}_{2}$ mixture as described by Page et al (1982); the total nitrogen was determined using the micro- Kjeldahl method, as described by the FAO (1982). According to Watanabe and Olsen (1965), phosphorus concentration was evaluated using a Spectrophotometer (SPAD-502Plus). Potassium content was measured with a Flame photometer (flame photometer 410) as reported by Chapman and Pratt (1961).

\subsubsection{Biochemical parameters in broccoli heads}

Total soluble solids (TSS) were examined using the refractometer (ATC 2E) (AOAC 1990). Additionally, vitamin $\mathrm{C}$ determinations were performed according to the protocol of Pearson (1970). Protein contents were calculated using data obtained from total nitrogen contents using the micro-Kjeldahl method (AOAC 1990).

\subsection{Statistical analysis}

Data were presented as a mean of at least three independent replicates and statistically analyzed using SAS program (SAS institute 2000). The difference among means was considered significant at $\mathrm{P} \leq 0.05$ referring to the LSD value according to Waller and Duncan (1969). 


\section{Results and Discussion}

\subsection{Growth regulators produced by $P$ s. fluo- rescens (Ps1)}

Analysis of King's medium, Ps. fluorescens (Ps1) supernatant revealed the capability to produce zeatin (ZE), gibberellins (GAs), and indole3 -acetic acid (IAA), with concentrations of 159.0, 45.1 , and $15.0 \mu \mathrm{g} / \mathrm{ml}$, respectively these results are compatible with those revealed by (Zayed et al 2017).

\subsection{Endomycorrhizal colonization as influenced by different treatments}

Results recorded in Table 4 show that using Ps. fluorescens (Ps1) as a helper had a stimulatory effect on plant root infection with endomycorrhizae Fig 1, while the uninoculated plants showed no endomycorrhizal colonization at any of the irrigation levels. These results are compatible with Pivato et al (2009) as they reported that Pseudomonas fluorescens C7R12 promoted both the growth and root colonization by Glomus mosseae BEG12, indicating that it acted as endomycorrhizal helper bacteria. Barea et al (1998) reported that two different strains of Pseudomonas fluorescens stimulated spores germinating and mycelial development of Glomus mosseae in the soil as well as plant root colonization.

Table 4. Percentage of arbuscular mycorrhizal fungi (AMF) root colonization in association with Ps. fluorescens (Ps1) under different irrigation levels (ETc)

\begin{tabular}{|c|c|c|}
\hline \multicolumn{2}{|c|}{ Treatments } & $\begin{array}{c}\text { AMF Root } \\
\text { colonization } \\
\%\end{array}$ \\
\hline \multirow{4}{*}{$50 \%$} & Control & 0 \\
\cline { 2 - 3 } ETc & AMF & 90 \\
\cline { 2 - 3 } & AMF and Ps. fluorescens & 96 \\
\cline { 2 - 3 } & Ps. fluorescens (Ps1) & 0 \\
\hline \multirow{4}{*}{$75 \%$} & Control & 0 \\
\cline { 2 - 3 } ETc & AMF & 81 \\
\cline { 2 - 3 } & AMF and Ps. fluorescens & 87 \\
\cline { 2 - 3 } & Ps. fluorescens (Ps1) & 0 \\
\hline \multirow{4}{*}{$100 \%$} & Control & 0 \\
\cline { 2 - 3 } ETc & AMF & 70 \\
\cline { 2 - 3 } & AMF and Ps. fluorescens & 78 \\
\cline { 2 - 3 } & Ps. fluorescens (Ps1) & 0 \\
\cline { 2 - 3 } & & \\
\hline
\end{tabular}

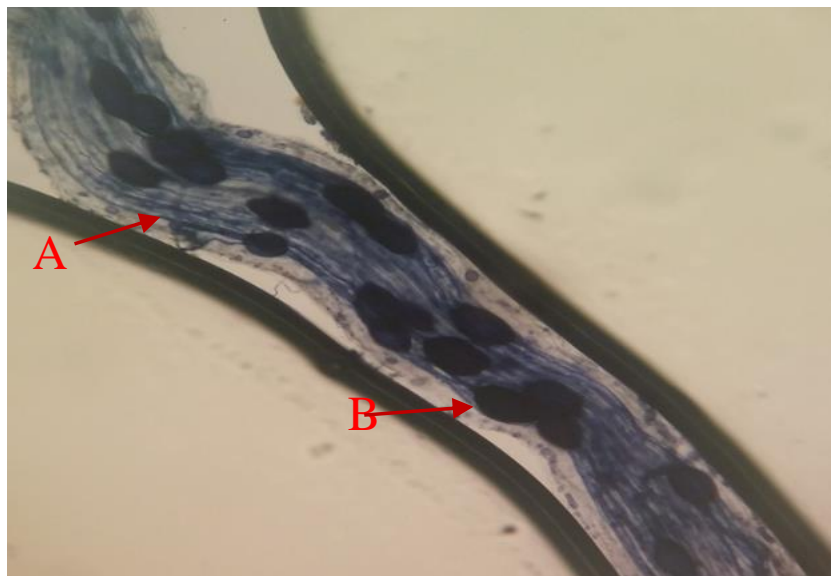

Fig 1. AMF fungal structures in Broccoli roots $A$ ) arbuscules B) vesicles

Intriguingly, the highest observed mycorrhizal colonization ratio was combined with inoculation with Ps. fluorescens (Ps1) under 50\% ETc followed by plants inoculated with endomycorrhizal spores only under the same ETc level being 96 and $90 \%$, respectively.

\subsection{Proliferation of Ps. fluorescens (Ps1)}

Data illustrated by Fig 2 reveal the average total viable count of Ps. fluorescens (Ps1) in the rhizosphere of broccoli plants as influenced by different water irrigation regimes and the combined inoculation with AMF in the two successive seasons 2019/2020.

Generally, at zero time the initial population density of Ps. fluorescens (Ps1) in the rhizosphere of broccoli plants in all treatments ranged approximately from 8.44 to $8.78 \times 10^{7} \mathrm{cfu} / \mathrm{g}$ dry rhizosphere soil. The population of Ps. fluorescens (Ps1) revealed a gradual increase in density followed by a slight decrease in all irrigation levels.

The densities of Ps. fluorescens (Ps1) as influenced by inoculation with AMF under 50\% ETc are plotted in Fig 2-a. The Ps. fluorescens (Ps1) density after 60 days of cultivation reached, $17.0 \times 10^{7}, 15.0 \times 10^{7}$, $11.2 \times 10^{7}$ and $12.6 \times 10^{7} \mathrm{cfu} / \mathrm{g}$ dry rhizosphere soil, in broccoli plants inoculated with AMF and Ps. fluorescens (Ps1), Ps. fluorescens (Ps1), AMF only and the uninoculated control in respective order.

Fig 2-b show that Ps. fluorescens (Ps1) density after 60 days of cultivation broccoli plants subjected to $75 \%$ ETc reached $4.2 \times 10^{7}, 12.5 \times 10^{7}, 9.9 \times 10^{7}$, and $7.5 \times 10^{7} \mathrm{cfu} / \mathrm{g}$ dry rhizosphere soil, in broccoli plants inoculated with AMF and Ps. fluorescens (Ps1), Ps. fluorescens (Ps1), AMF only and the control treatments in respective order. 
Data in Fig 2-c show that Ps. fluorescens (Ps1) density after 60 days of cultivation, reached 12.2 $\times 10^{7}, 9.1 \times 10^{7}, 7.9 \times 10^{7}$ and $6.4 \times 10^{7} \mathrm{cfu} / \mathrm{g}$ dry rhizosphere, in broccoli plants inoculated with AMF and Ps. fluorescens (Ps1), Ps. fluorescens (Ps1), AMF only and the control in respective order.
Our results are compatible with Manaf and Zayed (2015), Edwards et al (1998) who indicated that inoculation of plants with endomycorrhizae and Ps. fluorescens had a synergistic effect on the population of both microorganisms in addition to increasing mycorrhizal root colonization percentage.
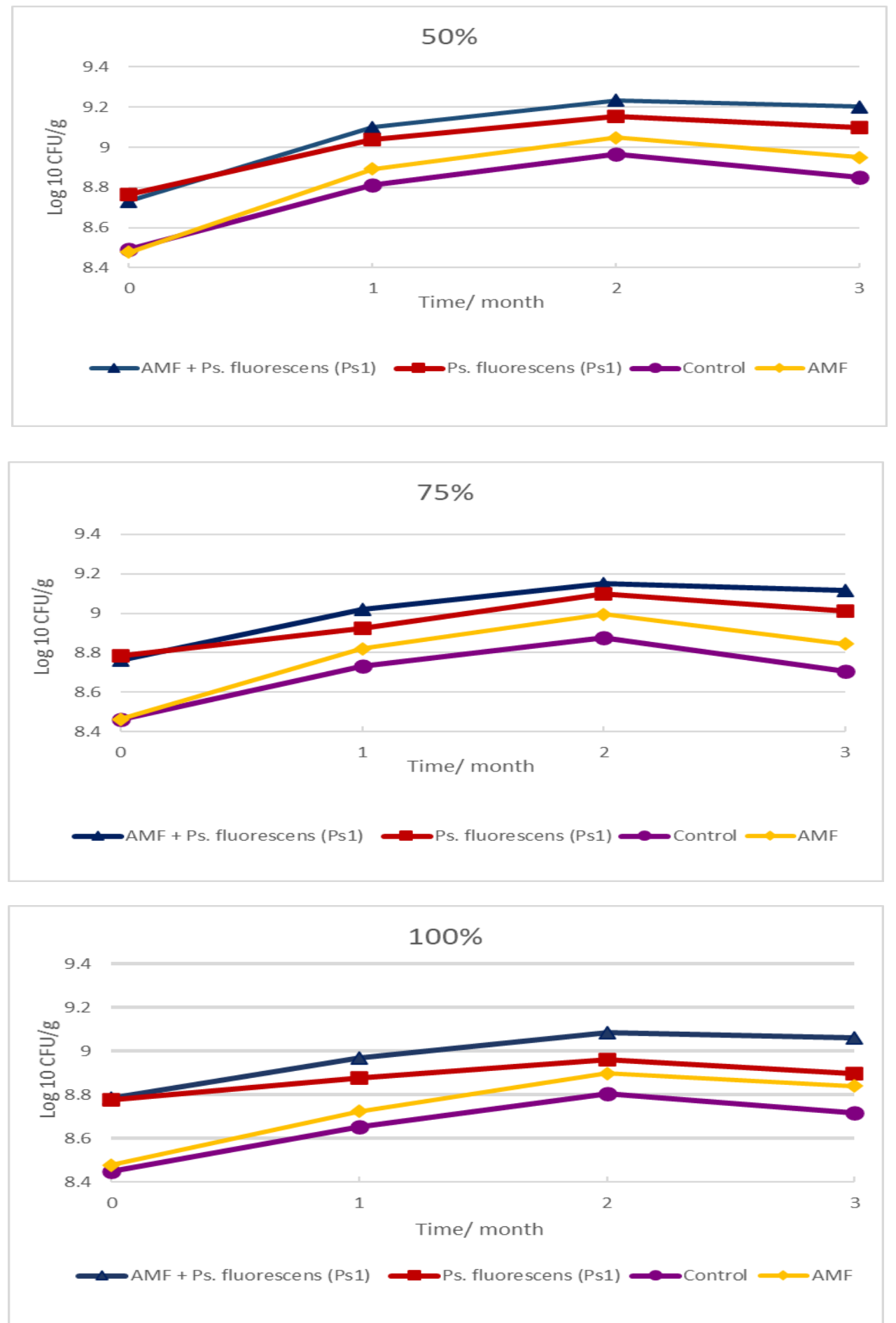

Fig 2. Ps. fluorescens (Ps1) counts in the rhizosphere of broccoli plants as affected by (A) $\% 50$ (B) $75 \%$ and (c) $100 \%$ of water requirements "irrigation levels" and the combined inoculation with AMF fungi. 


\subsection{Vegetative growth and yield of plants}

Data displayed in Table 5 reveal the influence of different ETc treatments and different microbial inocula on the growth parameters of broccoli plants during two successive seasons (2018-2019). Generally by estimating the effect of ETc it is clear that increasing the ETc reveals a significant increase in number of leaves, total plant fresh weight in the two successive seasons. The highest significant increases in number of leaves, total plant fresh weight were recorded with plants subjected to $100 \%$ ETc in the two seasons being 24.1 \& 23.3 and $985 \& 1028 \mathrm{~g} /$ plant respectively. While broccoli plants revealed a decrease in total chlorophyll by increasing the ETc, the highest significant total chlorophyll was recorded with plants subjected to $50 \%$ ETc being 63.1 and 60.3 $\mu \mathrm{g}$ Chl./cm respectively. The effect of different combinations between Ps. fluorescens (Ps1) and AMF on broccoli plants revealed that using both Ps. fluorescens (Ps1) and AMF on broccoli plants recorded the highest significant growth parameters in no. of leaves $(24.3 \& 23.8)$, total plant fresh weight (1208 and $1249 \mathrm{~g} /$ plant) and total chlorophyll 62.1 and $67.3 \mu \mathrm{g} \mathrm{Chl} . / \mathrm{cm}$ ) in both seasons respectively.
The different combinations between ETc and biofertilizers (Ps. fluorescens (Ps1) and AMF) revealed the highest significant No. of leaves and total plants fresh weight with plants subjected to 100 ETc and inoculated with (Ps. fluorescens (Ps1) and AMF) in the two seasons being $26.8 \& 26.4$ and $1365 \& 1501$ $\mathrm{g} /$ plant respectively, while the highest chlorophyll content was recorded with plants subjected to $50 \%$ ETc and inoculated with Ps. fluorescens (Ps1) and AMF being 68.6 and $68.2 \mu \mathrm{g} \mathrm{Chl} / \mathrm{cm}$ respectively.

It is clear in the current study that lower irrigation levels reduced the recorded plant growth parameters, which could be attributed to its effect on cells division in the meristems of the shoot and root as well as arresting cells growth. The reduction in photosynthetic rate induced by water scarcity is directly linked to the disturbance of cell division or expansion (Benabdellah et al 2011). In case of water stress, tissues to tissues' water balance are disturbed, and the loss of turgor has negatively impacted cell development, therefore the cells keep small. Furthermore, the synthesis of the cell wall is affected by the reduction in cell development, which subsequently causes shrinking leaves and decreasing photosynthesis (Abdrabbo et al 2015, Asghari 2008). As a result of decreasing photosynthesis, the protein and chlorophyll are negatively impacted (Chen et al 2013).

Table 5. Vegetative growth parameters of broccoli plants as influenced by different irrigation levels and microbial inoculants throughout the two studied seasons of 2018 and 2019

\begin{tabular}{|c|c|c|c|c|c|c|c|c|c|c|}
\hline \multirow{4}{*}{$\begin{array}{c}\text { Irrigation } \\
\text { level of ETc }\end{array}$} & \multicolumn{5}{|c|}{$1^{\text {st }}$ season } & \multicolumn{5}{|c|}{$2^{\text {nd }}$ season } \\
\hline & \multicolumn{5}{|c|}{ Microbial inocula } & \multicolumn{5}{|c|}{ Microbial inocula } \\
\hline & $\bullet \mathrm{AMF}$ & ${ }^{\bullet}$ Ps1 & AMF+Ps1 & Control & $\operatorname{Mean}(\mathrm{B})$ & $\cdot \mathbf{A M F}$ & ${ }^{\bullet \bullet P}$ Ps1 & AMF+Ps1 & Control & $\operatorname{Mean}(\mathbf{B})$ \\
\hline & \multicolumn{5}{|c|}{ No. of leaves } & \multicolumn{5}{|c|}{ No. of leaves } \\
\hline $50 \%$ & $21.2 \mathrm{i}$ & $21.7 \mathrm{~g}$ & $23.1 \mathrm{~d}$ & $21.5 \mathrm{~g}$ & $21.9 \mathrm{~B}$ & $20.6 \mathrm{~h}$ & $21.9 \mathrm{e}$ & $21.5 \mathrm{f}$ & $19.1 \mathrm{i}$ & $20.8 \mathrm{C}$ \\
\hline $75 \%$ & $22.2 \mathrm{e}$ & $21.4 \mathrm{~h}$ & $23.0 \mathrm{~d}$ & $21.9 \mathrm{f}$ & $22.1 \mathrm{~B}$ & $21.9 \mathrm{e}$ & $20.7 \mathrm{~g}$ & $23.4 \mathrm{~b}$ & $20.7 \mathrm{~g}$ & $21.7 \mathrm{~B}$ \\
\hline $100 \%$ & $25.0 \mathrm{~b}$ & $23.2 \mathrm{c}$ & $26.8 \mathrm{a}$ & $21.4 \mathrm{~h}$ & $24.1 \mathrm{~A}$ & $22.7 \mathrm{c}$ & $22.0 \mathrm{e}$ & $26.4 \mathrm{a}$ & $22.2 \mathrm{~d}$ & $23.3 \mathrm{~A}$ \\
\hline \multirow[t]{2}{*}{$\operatorname{Mean}(\mathrm{A})$} & $22.8 \mathrm{~B}$ & $22.1 \mathrm{C}$ & $24.3 \mathrm{~A}$ & $21.6 \mathrm{D}$ & & $21.7 \mathrm{~B}$ & $21.5 \mathrm{~B}$ & $23.8 \mathrm{~A}$ & $20.7 \mathrm{C}$ & \\
\hline & \multicolumn{5}{|c|}{ Total plant fresh weight (g/plant) } & \multicolumn{5}{|c|}{ Total plant fresh weight (g/plant) } \\
\hline $50 \%$ & $738 \mathrm{~g}$ & $539 \mathrm{i}$ & $998 \mathrm{e}$ & $473 \mathrm{j}$ & $687 \mathrm{~B}$ & $753 \mathrm{ef}$ & $539 \mathrm{i}$ & $1048 \mathrm{~d}$ & $449 \mathrm{j}$ & $697 \mathrm{C}$ \\
\hline $75 \%$ & $1090 \mathrm{~d}$ & $770 \mathrm{f}$ & $1260 \mathrm{~b}$ & $646 \mathrm{~h}$ & $941 \mathrm{~A}$ & $1068 \mathrm{~d}$ & $737 \mathrm{~g}$ & $1197 \mathrm{~b}$ & $569 \mathrm{~h}$ & $893 \mathrm{~B}$ \\
\hline $100 \%$ & $1161 \mathrm{c}$ & $737 \mathrm{~g}$ & $1365 \mathrm{a}$ & $675 \mathrm{~h}$ & $985 \mathrm{~A}$ & $1150 \mathrm{c}$ & $770 \mathrm{f}$ & $1501 \mathrm{a}$ & $689 \mathrm{~g}$ & $1028 \mathrm{~A}$ \\
\hline Mean (A) & $996 \mathrm{~B}$ & $682 \mathrm{C}$ & $1208 \mathrm{~A}$ & $598 \mathrm{C}$ & & $990 \mathrm{~B}$ & $682 \mathrm{C}$ & $1249 \mathrm{~A}$ & $569 \mathrm{D}$ & \\
\hline & \multicolumn{5}{|c|}{ Total chlorophyll $\mu \mathrm{g}$ Chl./cm (SPAD) } & \multicolumn{5}{|c|}{ Total chlorophyll $\mu \mathrm{g}$ Chl./cm (SPAD) } \\
\hline $50 \%$ & $67.5 \mathrm{~b}$ & $67.2 \mathrm{~b}$ & $68.6 \mathrm{a}$ & $49.1 \mathrm{~h}$ & $63.1 \mathrm{~A}$ & $64.1 \mathrm{c}$ & $60.2 \mathrm{~d}$ & $68.2 \mathrm{a}$ & $48.5 \mathrm{~h}$ & $60.3 \mathrm{~A}$ \\
\hline $75 \%$ & $61.1 \mathrm{~d}$ & $55.6 \mathrm{e}$ & $62.5 \mathrm{c}$ & $46.5 \mathrm{i}$ & $56.5 \mathrm{~B}$ & $57.0 \mathrm{f}$ & $58.0 \mathrm{e}$ & $67.9 \mathrm{a}$ & $46.7 \mathrm{i}$ & $57.4 \mathrm{~B}$ \\
\hline $100 \%$ & $54.3 \mathrm{f}$ & $53.2 \mathrm{~g}$ & $55.1 \mathrm{ef}$ & $40.9 \mathrm{j}$ & $50.9 \mathrm{C}$ & $58.1 \mathrm{e}$ & $56.0 \mathrm{~g}$ & $65.9 \mathrm{~b}$ & $45.8 \mathrm{j}$ & $56.4 \mathrm{~B}$ \\
\hline Mean (A) & $61.0 \mathrm{~A}$ & $58.6 \mathrm{~B}$ & $62.1 \mathrm{~A}$ & $45.5 \mathrm{C}$ & & $59.7 \mathrm{~B}$ & $58.1 \mathrm{~B}$ & $67.3 \mathrm{~A}$ & $47.0 \mathrm{C}$ & \\
\hline
\end{tabular}

•AMF Arbuscular mycorrhizal fungi, ${ }^{\bullet}$ Ps1 Pseudomonas fluorescens (Ps1) 
Data displayed in Table 6 present the influence of different ETc treatments and different combinations between AMF and Ps. fluorescens (Ps1) on the yield and quality parameters of broccoli plants during two successive seasons (2018, 2019).

Generally to estimate the effect of ETc it is clear that, $75 \%$ ETc revealed the highest significant increase in head weight, head length, and head width in the two successive seasons being 453 and $457 \mathrm{~g}$ /plant, 16.0 and $12.4 \mathrm{~cm}$ and 26.7 and $25.8 \mathrm{~cm}$, while no significant differences were recorded in the head length of broccoli plants subjected to $75 \%$ and $100 \%$ ETc.

The different combinations between AMF and Ps. fluorescens (Ps1) in Table 6 revealed that using both of Ps. fluorescens (Ps1) and AMF on broccoli plants recorded the highest significant yield and quality parameters in the two seasons being 465 and $476 \mathrm{~g} /$ plant for head weight, 18.8 and $15 \mathrm{~cm}$ for head length and 32.2 and $30.5 \mathrm{~cm}$ for head width respectively.
The different combination between ETc and biofertilizers (Ps. fluorescens (Ps1) and AMF) revealed the highest significant head weight and head width within plants subjected to $75 \%$ ETc and inoculated with (Ps. fluorescens (Ps1) and AMF) in the two successive seasons being 616 and $647 \mathrm{~g} /$ plant and 36.8 and 34.9 $\mathrm{cm}$ respectively. The highest significant head length in the first season was recorded within broccoli plants subjected to $75 \%$ ETc and inoculated by (Ps. fluorescens (Ps1) and $\mathrm{AMF}$ ) being $19.5 \mathrm{~cm}$ while in the second season was recorded within plants subjected to $100 \%$ ETc and inoculated by (Ps. fluorescens (Ps1) and AMF) being $15.9 \mathrm{~cm}$. The growth and biochemical constituents of plants could be elucidated by the capability of Pseudomonas spp. to stimulate some defense mechanisms in the plant toward biotic and abiotic stresses. For instance, they produce some biochemical signals such as indole acetic acid and gibberellins, leading to stimulation and boost the length, expanding surface area, and the number of root tips. Accordingly, nutrient uptake is improved, and plant fresh, dry weights and yield increased under stress conditions (Hussain et al 2016, Neetu et al 2012).

Table 6. Yield parameters of broccoli plants as influenced by different treatments throughout the two successive seasons of 2018 and 2019

\begin{tabular}{|c|c|c|c|c|c|c|c|c|c|c|}
\hline \multirow{4}{*}{$\begin{array}{c}\text { Irrigation } \\
\text { level } \\
\text { of ETc }\end{array}$} & \multicolumn{5}{|c|}{$1^{\text {st }}$ season } & \multicolumn{5}{|c|}{$2^{\text {nd }}$ season } \\
\hline & \multicolumn{5}{|c|}{ Microbial inocula } & \multicolumn{5}{|c|}{ Microbial inocula } \\
\hline & $\bullet \mathbf{A M F}$ & $\bullet$ Ps1 & AMF+Ps1 & Control & $\begin{array}{c}\text { Mean } \\
\text { (B) }\end{array}$ & $\cdot \mathbf{A M F}$ & $\bullet P s 1$ & AMF+Ps1 & Control & $\begin{array}{c}\text { Mean } \\
\text { (B) }\end{array}$ \\
\hline & \multicolumn{5}{|c|}{ Head weight (g/plant) } & \multicolumn{5}{|c|}{ Head weight (g/plant) } \\
\hline $50 \%$ & $353 \mathrm{~g}$ & $227 \mathrm{~h}$ & $370 \mathrm{f}$ & $149 \mathrm{j}$ & $275 \mathrm{C}$ & $258 \mathrm{~h}$ & $256 \mathrm{~h}$ & $332 \mathrm{~g}$ & $142 \mathrm{k}$ & $247 \mathrm{C}$ \\
\hline $75 \%$ & $568 \mathrm{~b}$ & $421 \mathrm{c}$ & $616 \mathrm{a}$ & $206 \mathrm{i}$ & $453 \mathrm{~A}$ & $559 \mathrm{~b}$ & $413 \mathrm{e}$ & $647 \mathrm{a}$ & $210 \mathrm{i}$ & $457 \mathrm{~A}$ \\
\hline $100 \%$ & $392 \mathrm{e}$ & $362 \mathrm{f}$ & $408 \mathrm{~d}$ & $203 \mathrm{i}$ & $341 \mathrm{~B}$ & $489 \mathrm{c}$ & $360 \mathrm{f}$ & $449 \mathrm{~d}$ & $178 \mathrm{j}$ & $369 \mathrm{~B}$ \\
\hline \multirow[t]{2}{*}{ Mean (A) } & $438 \mathrm{~B}$ & $337 \mathrm{C}$ & $465 \mathrm{~A}$ & $186 \mathrm{D}$ & & $435 \mathrm{~B}$ & $343 \mathrm{C}$ & $476 \mathrm{~A}$ & $177 \mathrm{D}$ & \\
\hline & \multicolumn{5}{|c|}{ Head length $(\mathrm{cm})$} & \multicolumn{5}{|c|}{ Head length $(\mathrm{cm})$} \\
\hline $50 \%$ & $16.5 \mathrm{e}$ & $10.8 \mathrm{i}$ & $18.7 \mathrm{~b}$ & $8.60 \mathrm{k}$ & $13.7 \mathrm{C}$ & $12.8 \mathrm{e}$ & $8.93 \mathrm{j}$ & $14.2 \mathrm{~cd}$ & $7.50 \mathrm{k}$ & $10.9 \mathrm{~B}$ \\
\hline $75 \%$ & $17.8 \mathrm{~cd}$ & $15.0 \mathrm{f}$ & $19.5 \mathrm{a}$ & $11.7 \mathrm{~h}$ & $16,0 \mathrm{~A}$ & $14.3 \mathrm{c}$ & $10.9 \mathrm{~h}$ & $15.0 \mathrm{~b}$ & $9.34 \mathrm{i}$ & $12.4 \mathrm{~A}$ \\
\hline $100 \%$ & $17.3 \mathrm{~d}$ & $14.1 \mathrm{~g}$ & $18.3 \mathrm{bc}$ & $9.83 \mathrm{j}$ & $14.9 \mathrm{~B}$ & $14.0 \mathrm{~d}$ & $11.3 \mathrm{~g}$ & $15.9 \mathrm{a}$ & $11.9 \mathrm{~h}$ & $13.3 \mathrm{~A}$ \\
\hline \multirow[t]{2}{*}{ Mean (A) } & $17.2 \mathrm{~A}$ & $13.3 \mathrm{~B}$ & $18.8 \mathrm{~A}$ & $10.0 \mathrm{C}$ & & $13.7 \mathrm{~B}$ & $10.4 \mathrm{C}$ & $15.0 \mathrm{~A}$ & $9.60 \mathrm{C}$ & \\
\hline & \multicolumn{5}{|c|}{ Head width $(\mathrm{cm})$} & \multicolumn{5}{|c|}{ Head width (cm) } \\
\hline $50 \%$ & $23.6 \mathrm{e}$ & $20.4 \mathrm{~g}$ & $27.8 \mathrm{~d}$ & $11.2 \mathrm{j}$ & $20.7 \mathrm{C}$ & $21.2 \mathrm{f}$ & $19.5 \mathrm{~g}$ & $24.6 \mathrm{e}$ & $12.7 \mathrm{i}$ & $19.5 \mathrm{C}$ \\
\hline $75 \%$ & $32.0 \mathrm{~b}$ & $21.9 \mathrm{f}$ & $36.8 \mathrm{a}$ & $16.1 \mathrm{~h}$ & $26.7 \mathrm{~A}$ & $29.9 \mathrm{c}$ & $24.3 \mathrm{e}$ & $34.9 \mathrm{a}$ & $14.2 \mathrm{~h}$ & $25.8 \mathrm{~A}$ \\
\hline $100 \%$ & $29.4 \mathrm{c}$ & $21.9 \mathrm{f}$ & $32.1 \mathrm{~b}$ & $14.2 \mathrm{i}$ & $24.4 \mathrm{~B}$ & $25.6 \mathrm{~d}$ & $21.2 \mathrm{f}$ & $32.0 \mathrm{~b}$ & $14.5 \mathrm{~h}$ & $23.3 \mathrm{~B}$ \\
\hline Mean $(\mathrm{A})$ & $28.3 \mathrm{~B}$ & $21.4 \mathrm{D}$ & $32.2 \mathrm{~A}$ & $13.8 \mathrm{C}$ & & $25.5 \mathrm{~B}$ & $21.6 \mathrm{C}$ & $30.5 \mathrm{~A}$ & $13.8 \mathrm{D}$ & \\
\hline
\end{tabular}

•AMF Arbuscular mycorrhizal fungi, ${ }^{\bullet}$ Ps1 Pseudomonas fluorescens (Ps1) 


\subsection{NPK contents in leaves}

Data in Table 7 shows the percentages of N, P, and $\mathrm{K}$ in broccoli plant leaves as influenced by different treatments throughout the 2018 and 2019 growing seasons.

Results show that the highest significant N, P, $\mathrm{K}$ contents in leaves were observed in $50 \%$ of ETc being $4.95,0.63$, and 2.55 in the first season and $5.00,0.62,2.45$ in the second season, respectively. Regarding using of different biofertilizers, the combined inoculation with AMF and Ps. fluorescens (Ps1) showed the highest significant content of $\mathrm{N}, \mathrm{P}$, and $\mathrm{K}$ in plant leaves being 4.88, 0.60 , and 2.61 in the first season and 4.79, 0.58 and 2.57 in the second season respectively.

Concerning irrigation and inoculation interaction, the treatment of 50\% ETc inoculated with $\mathrm{AMF}$ and Ps. fluorescens (Ps1) gave the highest significant nutrients content $(\mathrm{N}, \mathrm{P}$, and $\mathrm{K})$ in plant leaves. Different researchers recorded that increasing the irrigation water level causes an increase in the leachability of the nutrients from soil profile (Hashem et al 2014). Regarding the interaction among AMF and Ps. fluorescens (Ps1) it is clear that Ps. fluorescens (Ps1) enhances mutualistic interactions between plants and AMF, as well as the growth performance of mycorrhizal plants by causing better root structure that allows the extra radical hyphae to expand beyond plant rhizosphere depletion zones toward available moisture areas, which permitting more effective absorption of water and low-mobile nutrient under water stress (Qurashi and Sabri 2012, Giri et al 2004).

Table 8, shows the effect of different irrigation levels on biochemical constituents of broccoli head. The highest significant constituents were (6.22 and $6.50 \%)$ for TSS, (78.4 and $82.1 \mathrm{mg} / 100 \mathrm{~g} \mathrm{FW}$ ) for vitamin $\mathrm{C}$, and $(2.82$ and $2.60 \mathrm{~g} / 100 \mathrm{~g} \mathrm{FW})$ for protein were obtained when broccoli was supplied with irrigation water equal to $50 \%$ ETc.

The combined inoculation of broccoli plants by AMF and Ps. fluorescens (Ps1) significantly increased the TSS, vitamin $\mathrm{C}$, and protein, during the two studied seasons being 7.06 and $6.845 \%$ for TSS, 77.0 and $87.3 \mathrm{mg} / 100 \mathrm{~g}$ FW for vitamin $\mathrm{C}$ and 3.09 and 3.03 $\mathrm{g} / 100 \mathrm{~g} \mathrm{FW}$ for protein.

In respect of the interaction between different irrigation levels and microbial inoculants, data revealed that the highest significant head chemical compounds were obtained by combined inoculation of AMF and Ps. fluorescens (Ps1) under 50\% ETc during the two studied seasons being 7.47 and $7.56 \%$ for TSS, 85.2 and $98.3 \mathrm{mg} / 100 \mathrm{~g} \mathrm{FW}$ for vitamin $\mathrm{C}$ and 3.26 and $3.19 \mathrm{~g} / 100 \mathrm{~g} \mathrm{FW}$ for protein. While the lowest chemical compounds of broccoli plants were obtained by $100 \%$ ETc without inoculation. These results are compatible with (Emmanuel and Babalola 2020, Erdogan and Bagdatli 2017, Zhang et al 2011) who reported that mycorrhiza can delay drought effect

Table 7. Content of N, P, and $\mathrm{K}$ in leaves of broccoli plants as influenced by different treatments throughout the two seasons of 2018 and 2019

\begin{tabular}{|c|c|c|c|c|c|c|c|c|c|c|}
\hline \multirow{4}{*}{$\begin{array}{c}\text { Irrigation } \\
\text { level } \\
\text { of ETc }\end{array}$} & \multicolumn{5}{|c|}{ 1st season } & \multicolumn{5}{|c|}{ 2nd season } \\
\hline & \multicolumn{5}{|c|}{ Microbial inocula } & \multicolumn{5}{|c|}{ Microbial inocula } \\
\hline & $\bullet$ AMF & $\bullet$ Ps1 & AMF+Ps1 & Control & $\operatorname{Mean}(B)$ & \begin{tabular}{|l|} 
AMF \\
\end{tabular} & $\stackrel{\bullet P s 1}{ }$ & AMF+Ps1 & \begin{tabular}{|l|} 
Control \\
\end{tabular} & $\operatorname{Mean}(B)$ \\
\hline & \multicolumn{5}{|c|}{$\mathrm{N}(\%)$} & \multicolumn{5}{|c|}{$\mathbf{N}(\%)$} \\
\hline $50 \%$ & $5.39 \mathrm{~b}$ & $4.41 \mathrm{c}$ & $5.94 \mathrm{a}$ & 4.06 ef & $4.95 \mathrm{~A}$ & $5.10 \mathrm{~b}$ & $4.85 \mathrm{c}$ & $5.64 \mathrm{a}$ & $4.40 \mathrm{e}$ & $5.00 \mathrm{~A}$ \\
\hline $75 \%$ & $4.13 \mathrm{de}$ & $3.99 \mathrm{f}$ & $4.51 \mathrm{c}$ & $3.78 \mathrm{~g}$ & $4.10 \mathrm{~B}$ & $4.07 \mathrm{fg}$ & $3.99 \mathrm{~g}$ & $4.60 \mathrm{~d}$ & $3.47 \mathrm{j}$ & $4.03 \mathrm{~B}$ \\
\hline $100 \%$ & $3.85 \mathrm{~g}$ & $3.64 \mathrm{~h}$ & $4.21 \mathrm{~d}$ & $3.64 \mathrm{~h}$ & $3.83 \mathrm{C}$ & $3.82 \mathrm{~h}$ & $3.68 \mathrm{i}$ & $4.12 \mathrm{f}$ & $3.43 \mathrm{j}$ & $3.76 \mathrm{C}$ \\
\hline \multirow[t]{2}{*}{ Mean (A) } & $4.46 \mathrm{~B}$ & $4.01 \mathrm{C}$ & $4.88 \mathrm{~A}$ & $3.83 \mathrm{D}$ & & $4.33 \mathrm{~B}$ & $4.17 \mathrm{~B}$ & $4.79 \mathrm{~A}$ & $3.77 \mathrm{C}$ & \\
\hline & \multicolumn{5}{|c|}{$\mathbf{P}(\%)$} & \multicolumn{5}{|c|}{$\mathbf{P}(\%)$} \\
\hline $50 \%$ & $0.65 \mathrm{~b}$ & $0.63 \mathrm{~b}$ & $0.71 \mathrm{a}$ & $0.56 \mathrm{~b}$ & $0.63 \mathrm{~A}$ & $0.68 \mathrm{~b}$ & $0.56 \mathrm{c}$ & $0.72 \mathrm{a}$ & $0.51 \mathrm{~d}$ & $0.62 \mathrm{~A}$ \\
\hline $75 \%$ & $0.49 \mathrm{de}$ & $0.47 \mathrm{ef}$ & $0.58 \mathrm{c}$ & 0.47 ef & $0.50 \mathrm{~B}$ & $0.52 \mathrm{~d}$ & $0.45 \mathrm{ef}$ & $0.55 \mathrm{c}$ & $0.38 \mathrm{~g}$ & $0.47 \mathrm{~B}$ \\
\hline $100 \%$ & $0.43 \mathrm{~g}$ & $0.45 \mathrm{fg}$ & $0.51 \mathrm{~d}$ & $0.39 \mathrm{~h}$ & $0.44 \mathrm{~B}$ & $0.44 \mathrm{f}$ & $0.46 \mathrm{ef}$ & $0.48 \mathrm{e}$ & $0.33 \mathrm{~h}$ & $0.43 \mathrm{~B}$ \\
\hline \multirow[t]{2}{*}{ Mean (A) } & $0.52 \mathrm{~B}$ & $0.51 \mathrm{~B}$ & $0.60 \mathrm{~A}$ & $0.47 \mathrm{C}$ & & $0.54 \mathrm{~B}$ & $0.49 \mathrm{C}$ & $0.58 \mathrm{~A}$ & $0.41 \mathrm{D}$ & \\
\hline & \multicolumn{5}{|c|}{ K (\%) } & \multicolumn{5}{|c|}{$\mathrm{K}(\%)$} \\
\hline $50 \%$ & $2.62 \mathrm{c}$ & $2.55 \mathrm{~d}$ & $2.85 \mathrm{a}$ & $2.21 \mathrm{~g}$ & $2.55 \mathrm{~A}$ & $2.54 \mathrm{c}$ & $2.20 \mathrm{e}$ & $2.90 \mathrm{a}$ & $2.14 \mathrm{f}$ & $2.45 \mathrm{~A}$ \\
\hline $75 \%$ & $2.48 \mathrm{e}$ & $2.22 \mathrm{fg}$ & $2.72 \mathrm{~b}$ & $1.95 \mathrm{~g}$ & $2.34 \mathrm{~B}$ & $2.34 \mathrm{~d}$ & $2.20 \mathrm{e}$ & $2.66 \mathrm{~b}$ & $1.98 \mathrm{~h}$ & $2.30 \mathrm{~B}$ \\
\hline $100 \%$ & $2.08 \mathrm{~h}$ & $1.80 \mathrm{i}$ & $2.27 \mathrm{f}$ & $1.81 \mathrm{i}$ & $1.99 \mathrm{C}$ & $1.98 \mathrm{~h}$ & $2.08 \mathrm{~g}$ & $2.15 \mathrm{e}$ & $1.80 \mathrm{i}$ & $1.99 \mathrm{C}$ \\
\hline $\operatorname{Mean}(\mathrm{A})$ & $2.39 \mathrm{~B}$ & $2.19 \mathrm{C}$ & $2.61 \mathrm{~A}$ & $1.99 \mathrm{D}$ & & $2.29 \mathrm{~B}$ & $2.16 \mathrm{C}$ & $2.57 \mathrm{~A}$ & $1.97 \mathrm{D}$ & \\
\hline
\end{tabular}

•AMF -Arbuscular mycorrhizal fungi, ${ }^{\bullet} \mathrm{Ps} 1$ Pseudomonas fluorescens (Ps1) 
Table 8. TSS (\%), vitamin C, and protein contents in broccoli fruits as influenced by different treatments throughout the two seasons of 2018 and 2019

\begin{tabular}{|c|c|c|c|c|c|c|c|c|c|c|}
\hline \multirow{4}{*}{$\begin{array}{c}\text { Irrigation } \\
\text { level } \\
\text { of ETc }\end{array}$} & \multicolumn{5}{|c|}{ 1st season } & \multicolumn{5}{|c|}{ 2nd season } \\
\hline & \multicolumn{5}{|c|}{ Microbial inocula } & \multicolumn{5}{|c|}{ Microbial inocula } \\
\hline & $\bullet \mathbf{A M F}$ & Ps1 ${ }^{\bullet \bullet}$ & AMF+Ps1 & Control & $\operatorname{Mean}(B)$ & $\bullet \mathbf{A M F}$ & $\bullet^{\bullet P s 1}$ & AMF+Ps1 & Control & $\operatorname{Mean}(B)$ \\
\hline & \multicolumn{5}{|c|}{ TSS (\%) } & \multicolumn{5}{|c|}{ TSS (\%) } \\
\hline $50 \%$ & $6.53 \mathrm{~b}$ & $5.70 \mathrm{~d}$ & $7.47 \mathrm{a}$ & 5.18 ef & $6.22 \mathrm{~A}$ & $6.46 \mathrm{c}$ & $5.99 \mathrm{e}$ & $7.56 \mathrm{a}$ & $5.99 \mathrm{e}$ & $6.50 \mathrm{~A}$ \\
\hline $75 \%$ & $6.01 \mathrm{c}$ & $5.23 \mathrm{e}$ & $7.55 \mathrm{a}$ & $4.85 \mathrm{~g}$ & $5.91 \mathrm{~B}$ & $6.31 \mathrm{~d}$ & $6.19 \mathrm{~d}$ & $6.74 \mathrm{~b}$ & $5.45 \mathrm{f}$ & $6.17 \mathrm{~B}$ \\
\hline $100 \%$ & $5.15 \mathrm{f}$ & $4.71 \mathrm{~g}$ & $6.16 \mathrm{c}$ & $4.21 \mathrm{~h}$ & $5.06 \mathrm{C}$ & $4.98 \mathrm{~g}$ & $4.67 \mathrm{~h}$ & $6.21 \mathrm{~d}$ & $5.08 \mathrm{~g}$ & $5.23 \mathrm{C}$ \\
\hline \multirow[t]{2}{*}{$\operatorname{Mean}(\mathrm{A})$} & $5.89 \mathrm{~B}$ & $5.21 \mathrm{BC}$ & $7.06 \mathrm{~A}$ & $4.75 \mathrm{C}$ & & $5.91 \mathrm{~B}$ & $5.62 \mathrm{C}$ & $6.84 \mathrm{~A}$ & $5.51 \mathrm{C}$ & \\
\hline & \multicolumn{5}{|c|}{$\begin{array}{c}\text { Vitamin C } \\
(\mathrm{mg} / 100 \mathrm{~g} \text { FW) }\end{array}$} & \multicolumn{5}{|c|}{$\begin{array}{c}\text { Vitamin C } \\
(\mathrm{mg} / 100 \mathrm{~g} \mathrm{FW})\end{array}$} \\
\hline $50 \%$ & $83.0 \mathrm{~b}$ & $75.8 \mathrm{c}$ & $85.2 \mathrm{a}$ & $69.4 \mathrm{e}$ & $78.4 \mathrm{~A}$ & $87.7 \mathrm{~b}$ & $78.8 \mathrm{~d}$ & $98.3 \mathrm{a}$ & $63.4 \mathrm{~h}$ & $82.1 \mathrm{~A}$ \\
\hline $75 \%$ & $70.7 \mathrm{de}$ & $63.2 \mathrm{f}$ & $74.4 \mathrm{c}$ & $54.0 \mathrm{~h}$ & $65.6 \mathrm{~B}$ & $81.1 \mathrm{c}$ & $76.4 \mathrm{e}$ & $87.5 \mathrm{~b}$ & $72.8 \mathrm{f}$ & $79.5 \mathrm{~B}$ \\
\hline $100 \%$ & $63.4 \mathrm{f}$ & $57.6 \mathrm{~g}$ & $71.4 \mathrm{~d}$ & $45.6 \mathrm{i}$ & $59.5 \mathrm{C}$ & $69.3 \mathrm{~g}$ & $60.0 \mathrm{i}$ & $75.9 \mathrm{e}$ & $57.6 \mathrm{j}$ & $65.7 \mathrm{C}$ \\
\hline \multirow[t]{2}{*}{ Mean (A) } & $72.4 \mathrm{~B}$ & $65.5 \mathrm{C}$ & $77.0 \mathrm{~A}$ & $56.3 \mathrm{D}$ & & $79.4 \mathrm{~B}$ & $71.7 \mathrm{C}$ & $87.3 \mathrm{~A}$ & $64.6 \mathrm{D}$ & \\
\hline & \multicolumn{5}{|c|}{$\begin{array}{c}\text { Protein } \\
(\mathrm{g} / 100 \mathrm{~g} \text { FW }) \\
\end{array}$} & \multicolumn{5}{|c|}{$\begin{array}{c}\text { Protein } \\
(\mathrm{g} / 100 \mathrm{~g} \text { FW }) \\
\end{array}$} \\
\hline $50 \%$ & $3.24 \mathrm{a}$ & $2.43 \mathrm{~d}$ & $3.26 \mathrm{a}$ & $2.35 \mathrm{e}$ & $2.82 \mathrm{~A}$ & $2.88 \mathrm{~b}$ & $2.45 \mathrm{c}$ & $3.19 \mathrm{a}$ & $1.86 \mathrm{e}$ & $2.60 \mathrm{~A}$ \\
\hline $75 \%$ & $3.06 \mathrm{~b}$ & $2.30 \mathrm{e}$ & $3.11 \mathrm{~b}$ & $1.85 \mathrm{~g}$ & $2.58 \mathrm{~B}$ & $3.07 \mathrm{ab}$ & $2.26 \mathrm{~d}$ & $2.95 \mathrm{~b}$ & $1.53 \mathrm{f}$ & $2.45 \mathrm{~B}$ \\
\hline $100 \%$ & $2.83 \mathrm{c}$ & $2.12 \mathrm{f}$ & $2.90 \mathrm{c}$ & $1.82 \mathrm{~g}$ & $2.42 \mathrm{C}$ & $2.38 \mathrm{~d}$ & $1.95 \mathrm{e}$ & $2.95 \mathrm{~b}$ & $1.36 \mathrm{f}$ & $2.16 \mathrm{C}$ \\
\hline Mean $(\mathrm{A})$ & $3.04 \mathrm{~A}$ & $2.28 \mathrm{~B}$ & $3.09 \mathrm{~A}$ & $2.01 \mathrm{C}$ & & $2.78 \mathrm{~B}$ & $2.22 \mathrm{C}$ & $3.03 \mathrm{~A}$ & $1.58 \mathrm{D}$ & \\
\hline
\end{tabular}

•AMF Arbuscular mycorrhizal fungi, $\bullet$ Ps1 Pseudomonas fluorescens (Ps1)

according to colonization ratio, which may be varied as per irrigation levels, plant species, and some ecological parameters especially under the low irrigation level (Polcyn et al 2019).

It is clear from the previous data that, nutrient contents in the broccoli heads were lower under high irrigation levels compared to lower irrigation levels, which revealed the low quality of the yield. These results could be contributed to increasing irrigation level, increase humidity in plants, and decreasing solidity, which decreased the quality of broccoli (Hashem and Abd-Elrahman 2016).

\subsection{Water use efficiency (WUE)}

Data in Table 9 show the calculated WUE of broccoli plants under different irrigation levels and different combinations between AMF and $P s$. fluorescens (Ps1) during the two studied seasons of 2018 and 2019.

The treatment of $75 \%$ ETc showed the highest significant values of WUE $\left(2.34\right.$, and $\left.2.30 \mathrm{~kg} / \mathrm{m}^{3}\right)$ in the two seasons respectively.

The effect of microbial inoculants treatments on water use efficiency was significantly noticeable during both seasons. The combined inocula- tion of AMF and Ps. fluorescens (Ps1) gave the highest significant WUE being 2.54 and $2.49 \mathrm{~kg} / \mathrm{m}^{3}$ in the two seasons respectively followed by those inoculated by AMF. The lowest broccoli Water use efficiency was obtained with control groups during both seasons.

The combined inoculation of AMF and Ps. fluorescens (Ps1) combined with 75\% ETc gave the highest significant values compared to the other treatments being 3.18 and $3.26 \mathrm{~kg} / \mathrm{m}^{3}$ followed by $50 \%$ ETc under the same treatment being 2.87 and $2.51 \mathrm{~kg} / \mathrm{m}^{3}$ in the two seasons respectively. These results are agreed with those reported by (Langeroodi et al 2020, Rouphael et al 2015) who found that the addition of different combinations of biofertilizers especially the AMF improved the efficiency of water use and protect the plants from stress.

Increasing water use efficiency can be attributed to the combined inoculation of AMF and Ps. fluorescens (Ps1) as both of them improve the rate of delivering macro and micronutrients to the plants and improve crop resistance to water stress (Abdrabbo et al 2015). Supporting this notion, Jiao et al (2011) stated that inoculation of plants with AMF enhanced water use efficiency in vegetable plants through improving water absorption, leading to more efficient water usage. 
Table 9 Water use efficiency (WUE) of broccoli plants under different irrigation water levels and microbial inoculant types in the two seasons of 2018 and 2019.

\begin{tabular}{|c|c|c|c|c|c|c|c|c|c|c|}
\hline \multirow{4}{*}{$\begin{array}{c}\text { Irrigation } \\
\text { level } \\
\text { of ETc }\end{array}$} & \multicolumn{5}{|c|}{ 1st season } & \multicolumn{5}{|c|}{ 2nd season } \\
\hline & \multicolumn{5}{|c|}{ Microbial inocula } & \multicolumn{5}{|c|}{ Microbial inocula } \\
\hline & $\bullet \mathbf{A M F}$ & $\bullet P s 1$ & AMF+Ps1 & Control & $\begin{array}{c}\text { Mean } \\
\text { (B) }\end{array}$ & $\bullet \mathbf{A M F}$ & ${ }^{\bullet}$ Ps1 & AMF+Ps1 & Control & $\begin{array}{c}\text { Mean } \\
\text { (B) }\end{array}$ \\
\hline & \multicolumn{5}{|c|}{ WUE $\left(\mathrm{kg} / \mathrm{m}^{3}\right)^{\bullet \bullet \bullet}$} & \multicolumn{5}{|c|}{ WUE $\left(\mathrm{kg} / \mathrm{m}^{3}\right)$} \\
\hline $50 \%$ & $2.74 \mathrm{c}$ & $1.76 \mathrm{e}$ & $2.87 \mathrm{bc}$ & $1.16 \mathrm{~h}$ & $2.13 \mathrm{~A}$ & $1.95 \mathrm{~cd}$ & $1.93 \mathrm{def}$ & $2.51 \mathrm{~b}$ & $1.07 \mathrm{~g}$ & $1.87 \mathrm{~B}$ \\
\hline $75 \%$ & $2.94 \mathrm{~b}$ & $2.18 \mathrm{~d}$ & $3.18 \mathrm{a}$ & $1.06 \mathrm{~h}$ & $2.34 \mathrm{~A}$ & $2.81 \mathrm{~b}$ & $2.08 \mathrm{c}$ & $3.26 \mathrm{a}$ & $1.06 \mathrm{~g}$ & $2.30 \mathrm{~A}$ \\
\hline $100 \%$ & $1.52 \mathrm{efg}$ & $1.40 \mathrm{~g}$ & $1.58 \mathrm{ef}$ & $0.79 \mathrm{i}$ & $1.32 \mathrm{~B}$ & $1.85 \mathrm{ef}$ & $1.36 \mathrm{~g}$ & $1.70 \mathrm{f}$ & $0.67 \mathrm{~h}$ & $1.39 \mathrm{C}$ \\
\hline Mean $(\mathrm{A})$ & $2.40 \mathrm{~A}$ & $1.78 \mathrm{~B}$ & $2.54 \mathrm{~A}$ & $1.00 \mathrm{C}$ & & $2.20 \mathrm{~B}$ & $1.79 \mathrm{C}$ & $2.49 \mathrm{~A}$ & $0.93 \mathrm{D}$ & \\
\hline
\end{tabular}

•AMF Arbuscular mycorrhizal fungi, ${ }^{\bullet} \mathrm{Ps} 1$ Pseudomonas fluorescens (Ps1), ${ }^{\bullet \bullet W U E ~ W a t e r ~ u s e ~ e f f i c i e n c y ~}$

\section{Conclusion}

This study can assume that using vesicular arbuscular mycorrhizal fungi (AMF) and Ps. fluorescens (Ps1) in combination with $75 \%$ of ETc of irrigation level for broccoli plants was the promising combination to increase the productivity under water stress management. Additionally, using arbuscular mycorrhizal fungi (AMF) and Ps. fluorescens (Ps1) improved the leaves and fruit's nutrient content especially the quality characteristics when combined with a low level of irrigation water which saved macronutrients, increased WUE of the studied plants, and ameliorate the adaptability to stress.

\section{References}

Abdel-Salam EA, Alatar A, El-Sheikh MA (2017) Inoculation with Arbuscular Mycorrhizal Fungi Alleviates Harmful Effects of Drought Stress on Damask Rose. Saudi Journal of Biological Sciences $25,1772-1780$.

https://doi.org/10.1016/j.sjbs.2017.10.015

Abdrabbo MAA, Hashem FA, AbulSoud MA (2015) Sustainable Production of Cabbage using Different Irrigation Levels and Fertilizer Types Affecting some Soil Chemical characteristics. International Journal of Plant \& Soil Science 8, 113. http://dx.doi.org/10.9734/IJPSS/2015/17590

Ahanger MA, Tyagi S, Wani MR (2014) "Drought Tolerance: Role of Organic Osmolytes, Growth Regulators, and Mineral Nutrients," In: Ahmad P, Wani MR (Ed) Physiological Mechanisms and Adaptation Strategies in Plants under Changing Environment, Springer, New York, pp 25-55.

https://doi.org/10.1007/978-1-4614-8591-9 2
Allen RG, Pereira LS, Raes D (1998) Crop Evapotranspiration - Guidelines for computing crop water requirements - FAO Irrigation and Drainage paper 56, pp 15-79.

AOAC (1990) Official Methods of Analysis. $15^{\text {th }} \mathrm{Ed}$, Association of Official Analytical Chemists, Helrich K (Ed), Washington DC, USA. p 1015

Asghari HR (2008) Vesicular-arbuscular (VA) Mycorrhizae Improve Salinity Tolerance in Pre-inoculation Subterranean Clover (Trifolium subterraneum) Seedlings. International Journal of Plant Production 2, 243-256. https://dx.doi.org/10.22069/ijpp.2012.616

Barea JM, Andrade G, Bianciotto V (1998) Impact on Arbuscular Mycorrhiza Formation of Pseudomonas Strains Used as Inoculants for Biocontrol of SoilBorne Fungal Plant Pathogens. Applied and Environmental Microbiology 64, 2304-2307.

https://doi.org/10.1128/AEM.64.6.2304-2307.1998

Benabdellah K, Abbas Y, Abourouh M (2011) Influence of Two Bacterial Isolates from Degraded and Non-degraded Soils and Arbuscular Mycorrhizae Fungi Isolated from Semi-arid Zone on the Growth of Trifolium repens under Drought Conditions: Mechanisms Related to Bacterial Effectiveness. The European Journal of Soil Biology 47, 303-309.

https://doi.org/10.1016/j.ejsobi.2011.07.004

Chapman HD, Pratt PF (1961) Methods of Analysis for Soils, Plants and Waters. Soil Science. 93, p 68

Chen L, Dodd IC, Theobald JC (2013) The Rhizobacterium Variovorax paradoxus 5C-2, Containing ACC Deaminase, Promotes Growth and Development of Arabidopsis thaliana via an Ethylene-dependent Pathway. Journal of Experimental Botany 64, 15651573. https://doi.org/10.1093/jxb/ert031 
Cheng H, Zou Y, Wu Q (2021) Arbuscular Mycorrhizal Fungi Alleviate Drought Stress in Trifoliate Orange by Regulating $\mathrm{h}^{+}$-ATPase Activity and Gene Expression. Frontiers in Plant Science 12, 1-9. https://doi.org/10.3389/fpls.2021.659694

Durak E, Yildırım M (2017). Yield and Quality Compounds of Broccoli (Brassica oleracea L.cv. Beaumont) as Affected by Different Irrigation Levels. COMU Journal of Agriculture Faculty 5, 13-20.

Edwards SG, Young JPW, Fitter AH (1998). Interactions between Pseudomonas fluorescens Biocontrol Agents and Glomus mosseae, an Arbuscular Mycorrhizal Fungus, Within the Rhizosphere. FEMS Microbiology Letters 166, 297-303. https://doi.org/10.1111/j.1574-6968.1998.tb13904.x

Emmanuel OC, Babalola OO (2020). Productivity and Quality of Horticultural Crops through Co-inoculation of Arbuscular Mycorrhizal Fungi and Plant Growth Promoting Bacteria. Microbiological Research 239, 1-11.

https://doi.org/10.1016/j.micres.2020.126569

Erdogan O, Bagdatli MC (2017) The Effects of Arbuscular Mycorrhizal Fungi (AMF) and Deficit Irrigation Levels on Yield and Growth Parameters of the Silage Maize (Zea mays L.). Fresenius Environmental Bulletin 26, 2948-2955

FAO (1982) The State of Food and Agriculture. World Review Livestock Production: A World Perspective. Rome, Italy, Series No 15.

FAO (2012) The State of Food Insecurity in the World.

https://www.fao.org/3/i3027e/i3027e00.htm

Feddermann N, Finlay R, Boller T (2010) Functional Diversity in Arbuscular Mycorrhiza the Role of Gene Expression, Phosphorus Nutrition and Symbiotic Efficiency. Fungal Ecology 3, 1-8. https://doi.org/10.1016/j.funeco.2009.07.003

Giri B, Kapoor R, Agarwal L (2004) Preinoculation with Arbuscular Mycorrhizae Helps Acacia auriculiformis Grow in Degraded Indian Wasteland Soil. Communication in Soil Science and Plant Analysis 35, 193-204.

https://doi.org/10.1081/CSS-120027643

Hashem FA, Abdrabbo MAA, Abou-El-Hassan S (2014) Maximizing Water use Efficiency via Different Organic Mulches and Irrigation levels. Research Journal of Agriculture and Biological Sciences 10, 109-117.
Hashem FA, Abd-Elrahman SH (2016) Soil Chemical Characteristics and Growth of Broccoli and Cauliflower Plants as Affected by Liquid Organic Fertilizers and Irrigation Water Levels. Global Journal of Advanced Research 3, 881-895.

Hussain MJ, Rannu RP, Razzak MA (2016) Response of Broccoli (Brassica oleracia L.) to Different Irrigation Regimes. The Agriculturists 14, 98-106. https://doi.org/10.3329/agric.v14i1.29106

Jiao H, Chen Y, Lin X (2011) Diversity of Arbuscular Mycorrhizal Fungi in Greenhouse Soils Continuously Planted to Watermelon in North China. Mycorrhiza 21, 681-688.

https://doi.org/10.1007/s00572-011-0377-z

Jigme, Jayamangkala N, Sutigoolabud P (2015) The Effect of Organic Fertilizers on Growth and Yield of Broccoli (Brassica oleracea L. var. italica Plenck cv. Top Green). Journal of Organic Systems 10, 9-14.

King EO, Ward MK, Raney DE (1954) Two Simple Media for the Demonstration of Pyocyanin and Fluorescin. Journal of Laboratory and Clinical Medicine 44, 301-307.

Langeroodi ARS, Osipitan OA, Radicetti E (2020) To What Extent Arbuscular Mycorrhiza Can Protect Chicory (Cichorium intybus L.) Against Drought Stress. Scientia Horticulturae 263, 109-119.

https://doi.org/10.1016/j.scienta.2019.109109

Manaf HH, Zayed MS (2015) Productivity of Cowpea as Affected by Salt Stress in presence of Endomycorrhizae and Pseudomonas fluorescens. Annals of Agricultural Sciences 60, 219-226.

https://doi.org/10.1016/j.aoas.2015.10.013

Neetu N, Aggarwal A, Tanwar A (2012) Influence of Arbuscular Mycorrhizal Fungi and Pseudomonas fluorescens at Different superphosphate levels on Linseed (Linum usitatissimum L.) Growth Response. Chilean Journal of Agricultural Research 72, 237-243. http://dx.doi.org/10.4067/S0718-58392012000200012

Page AL, Miller RH, Keeney DR (1982) Methods of Soil Analysis, Part 2: Chemical and Microbiological Properties. American Society of Agronomy, Soil Science Society of America, Madison, Wisconsin, USA, p 1159.

Patle GT, Yadav SR, Pandey V (2018) Effect of Irrigation Levels and Mulching on Growth, Yield and Water use Efficiency of Cauliflower and Broccoli in Perhumid Ecoregion. Multilogic in Science 8, 188-191

Pearson D (1970) The Chemical Analysis of Foods. $6^{\text {th }}$ Ed, J \& A Churchill, Ltd., London, UK. 


\section{Arab Univ J Agric Sci (2021) 29 (3) 859-871}

Phillips JM, Hayman DS (1970) Improved Procedures for Clearing Roots and Staining Parasitic and Vesicular-Arbuscular Mycorrhizal Fungi for Rapid Assessment of Infection. Transactions of the British Mycological Society 55, 158-161. https://doi.org/10.1016/S0007-1536(70)80110-3

Pivato B, Offre P, Marchelli S (2009) Bacterial Effects on Arbuscular Mycorrhizal Fungi and Mycorrhiza Development as Influenced by the Bacteria, Fungi, and Host Plant. Mycorrhiza 19, 81-90. https://doi.org/10.1007/s00572-008-0205-2

Polcyn W, Paluch-Lubawa E, Lehmann T (2019) Arbuscular Mycorrhiza in Highly Fertilized Maize Cultures Alleviates Short-Term Drought Effects but Does Not Improve Fodder Yield and Quality. Frontiers in Plant Science 10, 496-511. https://doi.org/10.3389/fpls.2019.00496

Qessaoui R, Bouharroud R, Furze JN (2019) Applications of New Rhizobacteria Pseudomonas Isolates in Agroecology via Fundamental Processes Complementing Plant Growth. Scientific Reports 9, 1-10.

https://doi: 10.1038/s41598-019-49216-8

Qurashi AW, Sabri AN (2012). Bacterial Exopolysaccharide and Biofilm Formation Stimulate Chickpea Growth and Soil Aggregation under Salt Stress. Brazilian Journal of Microbiology 43, 1183-1191.

https://doi.org/10.1590/S1517-83822012000300046

Rouphael Y, Franken P, Schneider C et al (2015). Arbuscular Mycorrhizal Fungi Act as Biostimulants in Horticultural Crops. Scientia Horticulturae 196, 91-108. https://doi.org/10.1016/j.scienta.2015.09.002
Smith SE, Read DJ (2008). Mycorrhizal Symbiosis, $3^{\text {rd }}$ Ed. NY: Academic, New York, USA, pp 42-90.

Tien TM, Gaskins MH, Hubbell DH (1979) Plant Growth Substances Produced by Azospirillum brasilense and their Effect on the Growth of Pearl Millet (Pennisetum americanum L.). Applied and Environmental Microbiology 37, 1016-1024.

https://doi.org/10.1128/aem.37.5.1016-1024.1979

Waller RA, Duncan DB (1969) A Bayes Rule for the Symmetric Multiple Comparisons Problem, Journal of the American Statistical Association 64, 1484-1503. https://doi.org/10.2307/2286085

Watanabe FS, Olsen SR (1965) Test of an Ascorbic Acid Method for Determining Phosphorus in Water and $\mathrm{NaHCO}_{3}$ Extracts from Soils. Soil Science Society of America Journal 29, 677-678.

https://doi.org/10.2136/sssaj1965.0361599500290006 $0025 \mathrm{x}$

Zaicovski CB, Zimmerman T, Nora L (2008) Water Stress Increases Cytokinin Biosynthesis and Delays Postharvest Yellowing of Broccoli Florets. Postharvest Biology and Technology 49, 436-439. https://doi.org/10.1016/j.postharvbio.2008.02.001

Zayed MS, Hegazi GAEM, Salem HM (2017) Role of Endomycorrhizae and Pseudomonas fluorescens on the Acclimatization of Micropropagated Stevia rebaudiana Bert. plantlets. African Journal of Plant Science 11, 38-47. https://doi.org/10.5897/AJPS2016.1494

Zhang GY, Zhang LP, Wei MF (2011) Effect of Arbuscular Mycorrhizal Fungi, Organic Fertilizer and Soil Sterilization on Maize Growth. Acta Ecologica Sinica 31, 192-196.

https://doi.org/10.1016/j.chnaes.2011.04.005 